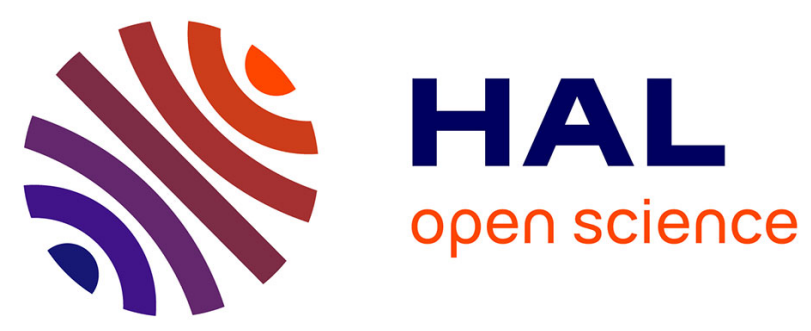

\title{
What is the ocular phenotype associated with a single exon 78 deletion in Duchenne muscular dystrophy?
}

Tuy Nga Brignol, Dominique Mornet, Cecilia Montañez, Dora Fix Ventura, Cyrille Vaillend, Alvaro Rendon

\section{- To cite this version:}

Tuy Nga Brignol, Dominique Mornet, Cecilia Montañez, Dora Fix Ventura, Cyrille Vaillend, et al.. What is the ocular phenotype associated with a single exon 78 deletion in Duchenne muscular dystrophy?. Journal of Human Genetics, 2020, 65 (8), pp.715-716. 10.1038/s10038-020-0755-5 . hal02640159

\section{HAL Id: hal-02640159 \\ https://hal.science/hal-02640159}

Submitted on 30 Jun 2020

HAL is a multi-disciplinary open access archive for the deposit and dissemination of scientific research documents, whether they are published or not. The documents may come from teaching and research institutions in France or abroad, or from public or private research centers.
L'archive ouverte pluridisciplinaire HAL, est destinée au dépôt et à la diffusion de documents scientifiques de niveau recherche, publiés ou non, émanant des établissements d'enseignement et de recherche français ou étrangers, des laboratoires publics ou privés. 


\title{
What is the ocular phenotype associated with a single exon 78 deletion in Duchenne muscular dystrophy?
}

\author{
Tuy Nga Brignol ${ }^{1}$. Dominique Mornet $^{2}$. Cecilia Montañez ${ }^{3}$. Dora Fix Ventura ${ }^{4} \cdot$ Cyrille Vaillend $^{5}$. \\ Alvaro Rendón 6
}

\section{To the Editor:}

We have read with great interest the Brief Communication reporting for the first time a clinical and histopathological description related to a single exon 78 deletion in Duchenne muscular dystrophy (DMD) gene. The 13-year-old male patient suffered from myalgia after exertion, with persistent increase of serum creatine kinase. Muscle fibers morphology and architecture were minimally affected. Height and weight were above 70 th percentile. Intellectual functions were normal [1].

In the discussion, the authors quoted a study about abnormal splicing of DMD exon 78 in dystrophic muscles in myotonic dystrophy type 1 (DM1). According to this study, during muscle development, the switch from embryonic to adult isoforms of dystrophin involved coordinated alternative splicing of two regions of the DMD gene: exons 71-74 and exon 78. Experimental abnormal splicing switch compromised muscle development, and muscle fiber maintenance.

Tuy Nga Brignol

tnbrignol@afm-telethon.fr

1 Medical Affairs Department, The French Muscular Dystrophy, Association (AFM-Telethon), Evry, France

2 PhyMedExp, Université de Montpellier, INSERM, CNRS, Montpellier, France

3 Departamento de Genética y Biología Molecular, Centro de Investigación y de Estudios Avanzados del IPN, Ciudad de, México, Mexico

4 Department of Experimental Psychology, Institute of Psychology, Universidade de São Paulo, Av. Prof. Mello Moraes 1721, Cidade Universitária, São Paulo, SP CEP 05508-030, Brazil

5 Paris-Saclay Institute of Neuroscience, UMR 9197, Université Paris Sud, CNRS, Université Paris Saclay, F-91405 Orsay, France

6 Sorbonne Université, INSERM, CNRS, Institut de la Vision, 17 rue Moreau, F-75012 Paris, France
These findings correlated with abnormalities described in skeletal muscle biopsies of DM1 patients.

In addition, we would like to bring the authors' attention to a study published in 2018 [2]. It shows that in adult mouse brain and retina, different dystrophin Dp71 isoforms were produced by alternative splicing of exons 71-74 and 78, being the isoforms differentially expressed in both tissues.

Since the beginning of 2010 , it is well established that Dp427 was notably expressed in bipolar cells and proportionally more expressed in cone- than in rod-associated synapses compared with Dp260, while Dp427, Dp260, Dp140, and Dp71 are expressed in inner nuclear layer neurons [3]. Note also that cognitive impairment was also linked to the role of various forms of dystrophin in the central nervous system. Dp427 and Dp71 were thus shown to be involved in synapse organization and function, and distinct Dp71 spliced variants (including those lacking exon 78) were detected in different neuronal subdomains [4]. It was demonstrated with recent approaches that the loss of mammalian brain dystrophins (Dp427, Dp71) impacts on the ultrastructural organization of central glutamatergic synapses, which may explain some of the alterations of synapse function and plasticity that contribute to intellectual disability in DMD [5]. Furthermore, studies on Dp71-null mice eye showed retina lesions with vascular inflammation and degeneration [6].

Retinal function by electroretinography was already studied in the 90's for Becker muscular dystrophy and DMD patients. Most of them had abnormal electroretinograms with reduced amplitude of the b-wave under scotopic conditions [7].

Moreover, in 2007, a study evaluating color vision in 44 DMD patients, 32 of which with deletion downstream of exon 30 , showed that $66 \%$ among those had a red-green color defect. No color defect was found in the 12 patients with deletion upstream of exon 30 [8].

According to more recent studies in DMD patients and heterozygous DMD carriers, dystrophin is required for the 
proper function of retinal mechanisms underlying ON-OFF, contrast sensitivity, luminance and red-green cone opponent responses [9, 10]. In fact, using the $\mathrm{mdx} 3 \mathrm{Cv}$ mice as a DMD model, a full demonstration between the asymmetrical ON versus OFF ERG alterations under mesopic versus photopic vision was recently described. As gene therapy was obtained in dystrophin Dp71 deficient mice with efficient blood-retinal barrier restoration and edema reabsorption [11], this leads us to draw the attention of our colleagues to the important potential clinical analyzes that they might consider in the hope of better management of the quality of life of such a patient.

Taken these data together, we suggest the authors to propose, if not done yet, an examination of visual function including color vision, contrast sensitivity, and electroretinography, along with a retinal optical coherence tomography, to this patient with exon 78 deletion in DMD gene.

\section{Compliance with ethical standards}

Conflict of interest The authors declare that they have no conflict of interest.

\section{References}

1. Traverso M, Assereto S, Baratto S, Iacomino M, Pedemonte M, Diana MC, et al. Clinical and molecular consequences of exon 78 deletion in DMD gene. J Hum Genet. 2018;63:761-4.
2. Aragón J, González-Reyes M, Romo-Yáñez J, Vacca O, AguilarGonzález G, Rendón A, et al. Dystrophin Dp71 isoforms are differentially expressed in the mouse brain and retina: report of new alternative splicing and a novel nomenclature for Dp71 isoforms. Mol Neurobiol. 2018;55:1376-86.

3. Wersinger E, Bordais A, Schwab Y, Sene A, Bénard R, Alunni V, et al. Reevaluation of dystrophin localization in the mouse retina. Investig Ophthalmol Vis Sci. 2011;52:7901-8.

4. Daoud F, Candelario-Martínez A, Billard JM, Avital A, Khelfaoui M, Rozenvald Y, et al. Role of mental retardation-associated dystrophin-gene product Dp71 in excitatory synapse organization, synaptic plasticity and behavioral functions. PLoS ONE. 2008;4: e6574.

5. Miranda R, Nudel U, Laroche S, Vaillend C. Altered presynaptic ultrastructure in excitatory hippocampal synapses of mice lacking dystrophins Dp427 or Dp71. Neurobiol Dis. 2011;43:134-41.

6. El Mathari B, Sene A, Charles-Messance H, Vacca O, Guillonneau X, Grepin C, et al. Dystrophin Dp71 gene deletion induces retinal vascular inflammation and capillary degeneration. Hum Mol Genet. 2015;24:3939-47.

7. Sigesmund DA, Weleber RG, Pillers DA, Westall CA, Panton CM, Powell BR, et al. Characterization of the ocular phenotype of Duchenne and Becker muscular dystrophy. Ophthalmology. 1994;101:856-65.

8. Costa MF, Oliveira AG, Feitosa-Santana C, Zatz M, Ventura DF. Red-green color vision impairment in Duchenne muscular dystrophy. Am J Hum Genet. 2007;80:1064-75.

9. Barboni MT, Nagy BV, de Araújo Moura AL, Damico FM, da Costa MF, Kremers J, et al. ON and OFF electroretinography and contrast sensitivity in Duchenne muscular dystrophy. Investig Ophthalmol Vis Sci. 2013;54:3195-204.

10. Barboni MT, Martins CM, Nagy BV, Tsai T, Damico FM, da Costa MF, et al. Dystrophin is required for proper functioning of luminance and red-green cone opponent mechanisms in the human retina. Investig Ophthalmol Vis Sci. 2016;57:3581-7.

11. Vacca O, Charles-Messance H, El Mathari B, Sene A, Barbe P, Fouquet $\mathrm{S}$, et al. AAV-mediated gene therapy in Dystrophin-Dp71 deficient mouse leads to blood-retinal barrier restoration and oedema reabsorption. Hum Mol Genet. 2016;25:3070-9. 